Jurnal Pendidikan Matematika : Judika Education

Volume 1, Nomor 1, Januari-Juni 2018

e-ISSN : 2614-6088

p-ISSN : 2620-732X

DOI: https://doi.org/10.31539/judika.v1i1.184

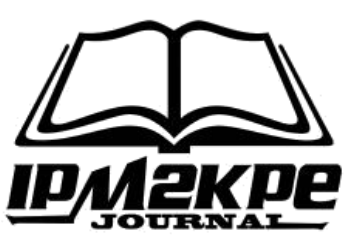

\title{
PENGARUH MODEL PEMBELAJARAN BERBASIS MASALAH TERHADAP KEMAMPUAN PEMECAHAN MASALAH MATEMATIKA
}

\author{
Maria Luthfiana ${ }^{1}$, Yuliansyah $^{2}$, Anna Fauziah ${ }^{3}$ \\ STKIP PGRI Lubuklinggau ${ }^{1,2,3}$ \\ maria_luthfiana@yahoo.co.id ${ }^{1}$
}

\begin{abstract}
ABSTRAK
Tujuan penelitian ini adalah untuk mengatahui pengaruh model pembelajaran berbasis masalah terhadap kemampuan pemecahan masalah matematika siswa kelas XI IPA MA Negeri 1 Lubuklinggau. Metode penelitian yang digunakan adalah true eksperimental design yang dilakukan dengan adanya kelompok pembanding. Populasi penelitian ini adalah seluruh siswa kelas XI IPA MA Negeri 1 Lubuklinggau, yang terdiri dari 113 siswa. Sebagai kelas eksperimen adalah kelas XI IPA 3 sebanyak 36 siswa dan sebagai kelas kontrol adalah kelas XI IPA 2 sebanyak 38 siswa yang dipilih secara acak. Pengumpulan data dilakukan dengan teknik tes bentuk uraian. Data yang terkumpul dianalisis menggunakan uji-t. Berdasarkan hasil analisis uji-t pada taraf signifikasi $\alpha 0,05$, diperoleh $(6,80)>(1,671)$. Simpulan, ada pengaruh model pembelajaran berbasis masalah terhadap kemampuan pemecahan masalah matematika siswa kelas XI IPA MA Negeri 1 Lubuklinggau.
\end{abstract}

Kata Kunci: Kemampuan Pemecahan Masalah Matematika, Pembelajaran Berbasis Masalah.

\begin{abstract}
The purpose of this study was to determine the effect of problem-based learning models on the mathematical problem solving ability of students of class XI IPA MA Negeri 1 Lubuklinggau. The research method used is true experimental design conducted by the comparison group. The study population was all students of class XI IPA MA Negeri 1 Lubuklinggau, which consisted of 113 students. As an experimental class is class XI Science 3 as many as 36 students and as a control class is class XI Science 2 as many as 38 students selected randomly. Data collection was carried out by means of a descriptive test form. The collected data were analyzed using t-test. Based on the results of the t-test analysis at the significance level $\alpha$ 0.05, obtained (6.80)> (1.671). Conclusion, there is an influence of problem-based learning models on the ability to solve math problems in class XI IPA MA Negeri 1 Lubuklinggau.
\end{abstract}

Keywords: Mathematical Problem Solving Ability, Problem Based Learning. 


\section{PENDAHULUAN}

Matematika merupakan ilmu pengetahuan yang mendasari ilmu pengetahuan lain dan perkembangan teknologi. Oleh karena itu, matematika perlu dipelajari oleh semua siswa dari sekolah dasar, menengah hingga perguruan tinggi. Suherman, et al. (2001) menyatakan bahwa para pelajar memerlukan matematika untuk memenuhi kebutuhan praktis dan memecahkan masalah dalam kehidupan sehari-hari.

Cornelius (Abdurrahman, 2012) juga mengemukakan lima alasan perlunya belajar matematika karena matematika merupakan: 1) sarana berpikir yang jelas dan logis, 2) sarana untuk memecahkan masalah kehidupan sehari-hari, 3) sarana mengenal pola-pola hubungan dan generalisasi pengalaman,4) sarana untuk mengembangkan kreativitas, dan 5) sarana untuk meningkatkan kesadaran terhadap perkembangan budaya.

Dari berbagai alasan perlunya mengajarkan matematika kepada siswa di atas, dapat disimpulkan bahwa matematika diperlukanuntuk memecahkan masalah yang muncul dalam kehidupan sehari-hari dengan menerapkan ilmu matematika yang sesuai.

Oleh karena itu, kemampuan memecahkan masalah seharusnya menjadi fokus utama dari kegiatan pembelajaran matematika. Gagasan ini sejalan dengan salah satu agenda yang dicanangkan National Council of
Teachers of Mathematics (NCTM) di Amerika Serikat pada tahun 80-an yang memfokuskan pemecahan masalah dalam matematika sekolah (Suherman, et al., 2001).

Berdasarkan hasil studi pendahuluan yang dilakukan di MA Negeri 1 Lubuklinggau, menunjukkan bahwa kemampuan siswa kelas $\mathrm{X}$ dalam memecahkan masalah masih tergolong kurang. Dibuktikan dengan skor rata-rata yang diperoleh siswa hanya 15,74 dari skor maksimal 30 . Terdapat 37 siswa atau 19,78\% yang memperoleh skor $\geq 20$, dan 150 siswa atau $80,22 \%$ yang memperoleh skor < 20. Hal ini menunjukkan bahwa kemampuan siswa kelas $\mathrm{X}$ dalam memecahkan masalah masih tergolong kurang.

Kurangnya kemampuan siswa memecahkan masalah sebagian besar terletak pada tahap me rencanakan penyelesaian masalah. Hal ini kurang sesuai dengan kemampuan akademik siswa yang tergolong cukup. Rata-rata hasil ulangan harian siswa kelas $\mathrm{X}$ sebesar 76,02. Tercatat 112 siswa atau $59,89 \%$ tuntas dalam ulangan harian dengan Kriteria Ketuntasan Minimal (KKM) sebesar 75. Sisanya sebanyak 75 siswa atau $40,11 \%$ belum tuntas dalam ulangan harian.

Berdasarkan wawancara dengan guru matematika kelas $\mathrm{X}$, model pembelajaran yang diterapkan pada siswa kelas X MA Negeri 1 Lubuklinggau disesuaikan dengan pendekatan saintifik. Namun, sesuai dengan kebijakan penundaan 
pemberlakuan kurikulum 2013 oleh Kementerian Pendidikan dan Kebudayaan, maka pembelajaran matematika kembali menggunakan model dan metode yang berpola teacher centered (berpusat pada guru).

Pergeseran ini memiliki kemungkinan sebagai penyebab kurangnya kemampuan siswa dalam memecahkan masalah. Padahal, pembelajaran menggunakan pendekatan saintifik mendorong dan menginspirasi siswa berpikir secara kritis, analitis, dan tepat dalam mengidentifikasi, memahami, memecahkan masalah, dan mengaplikasikan materi pembelajaran (Hosnan, 2014). Salah satu upaya yang dapat dilakukan untuk mengatasi kurangnya kemampuan siswa memecahkan masalah adalah menerapkan model pembelajaran berbasis masalah.

Pembelajaran berbasis masalah merupakan model pembelajaran yang menerapkan pendekatan scientific. Sani (2014) mengatakan bahwa pembelajaran berbasis masalah diawali dengan penyajian masalah nyata, mengajukan pertanyaanpertanyaan, memfasilitasi penyelidikan, dan membuka dialog.

Pembelajaran berbasis masalah menjadikan masalah nyata sebagai pemicu bagi proses belajar peserta didik sebelum mereka mengetahui konsep formal. Siswa secara kritis mengidentifikasi informasi dan strategi yang relevan serta melakukan penyelidikan untuk menyelesaikan masalah tersebut. Dengan menyelesaikan masalah tersebut, siswa memperoleh atau membangun pengetahuan tertentu dan sekaligus mengembangkan kemampuan berpikir kritis dan keterampilan menyelesaikan masalah.

Pembelajaran berbasis masalah, pusat pembelajaran adalah siswa (student- centered), sementara guru berperan sebagai fasilitator yang memfasilitasi peserta didik untuk secara aktif menyelesaikan masalah dan membangun pengetahuannya secara berpasangan ataupun berkelompok (Hosnan, 2014).

Adapun tujuan penelitian ini adalah untuk mengatahui pengaruh model pembelajaran berbasis masalah terhadap kemampuan pemecahan masalah matematika siswa kelas XI IPA MA Negeri 1 Lubuklinggau.

\section{METODE PENELITIAN}

Metode penelitian yang digunakan dalam penelitian ini adalah true eksperimental design. Populasi dalam penelitian ini adalah siswa kelas XI IPA MA Negeri 1 Lubuklinggau. Teknik pengambilan sampel menggunakan teknik simple random sampling. Setelah dilakukan pengundian, terpilih kelas XI IPA 3 sebanyak 36 siswa sebagai kelas eksperimen yang diberi perlakuan dengan model pembelajaran berbasis masalah dan kelas XI IPA 2 sebanyak 38 siswa sebagai kelas kontrol yang 
diberi perlakuan dengan model pembelajaran konvensional.

Teknik pengumpulan data yang digunakan adalah teknik tes. Tes dilakukan dua kali dengan rincian satu kali sebelum pembelajaran (pre-test) dan satu kali sesudah pembelajaran (post-test) pada materi peluang dengan sub materi kaidah pencacahan. Bentuk tes adalah soal uraian tentang kemampuan pemecahan masalah matematika sebanyak empat soal.

\section{HASIL PENELITIAN}

Penelitian ini dilakukan langsung oleh peneliti sesuai dengan jadwal pelajaran matematika yang berlaku di kelas XI IPA MA Negeri 1 Lubuklinggau.Dalam pelaksanaannya, pada kelas eksperimen peneliti melakukan lima kali pertemuan dengan rincian satu kali pertemuan mengadakan tes kemampuan awal (pre-test), tiga kali pertemuan mengadakan perlakuan pembelajaran menggunakan model pembelajaran berbasis masalah, dan satu kali pertemuan lagi mengadakan tes kemampuan akhir (post-test). Sedangkan pada kelas kontrol peneliti hanya mengadakan pertemuan pre-test dan post- test.

\section{Data Hasil Pre- Test}

Pelaksanaan pre-test bertujuan untuk mengetahui kemampuan pemecahan masalah matematika awal siswa sebelum diberikan pembelajaran. Pre-test di kelas eksperimen maupun kelas kontrol dilakukan setelah dilakukannya uji coba instrumen. Berdasarkan hasil perhitungan, rata-rata skor pre-test yang diperoleh kelas eksperimen adalah sebesar 7,92 dan rata- rata skor pre-test yang diperoleh kelas kontrol sebesar adalah 9,68. Secara deskriptif, kemampuan pemecahan masalah matematika awal siswa antara kelas eksperimen dan kelas kontrol tidak terdapat perbedaan yang begitu besar.

\section{Data Hasil Post-Test}

Pelaksanaan post-test bertujuan untuk mengetahui kemampuan pemecahan masalah matematika akhir siswa setelah diberikan pembelajaran menggunakan model pembelajaran berbasis masalah pada kelas eksperimen dan model pembelajaran konvensional pada kelas kontrol. Berdasarkan hasil perhitungan, ratarata skor post-test yang diperoleh kelas eksperimen adalah sebesar 32,44 dan rata-rata skor post-test yang diperoleh kelas kontrol adalah sebesar 24,55.

Berdasarkan hasil pre-test dan post-test dapat dilihat bahwa terdapat peningkatan kemampuan pemecahan masalah matematika pada kelas eksperimen sebesar 24,52 dan pada kelas kontrol sebesar 14,87. Perbandingan kemampuan pemecahan masalah matematika awal dan kemampuan pemecahan masalah matematika akhir pada kelas eksperimen dan kelas kontrol dapat dilihat pada grafik berikut ini: 


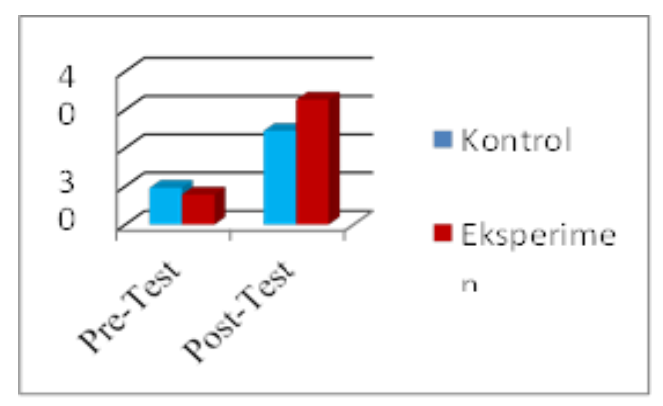

Grafik 1: Rata-rata Skor Hasil Pre-Test dan Post-Test

\section{Pengujian Hipotesis}

Analisis Inferensial Data PreTest Uji Normalitas. Uji normalitas dilakukan untuk mengetahui apakah data yang diperoleh berdistribusi normal atau tidak. Rumus yang digunakan untuk menghitung uji normalitas adalah chi kuadrat dengan taraf signifikasi $=0,05$, jika $<$, maka dapat dinyatakan bahwa data berdistribusi normal. Rekapitulasi hasil uji normalitas data pre- test pada kelas eksperimen dan kelas kontrol dapat dilihat pada tabel 1 .

Tabel 1.

Rekapitulasi Hasil Uji Normalitas Data Pre-Test

\begin{tabular}{llllll}
\hline No & \multicolumn{1}{c}{ Kelas } & \multicolumn{3}{c}{ k } & Kesimpulan \\
\hline 1 & Eksperimen & 4,8718 & 5 & 11,070 & Normal \\
\hline 2 & Kontrol & 5,4038 & 6 & 12,592 & Normal \\
\hline
\end{tabular}

Dari tabel 1 di atas dapat dilihat bahwa data pre-test untuk kelas eksperimen dan kelas kontrol kurang dari (<). Berdasarkan ketentuan uji normalitas dengan menggunakan chi kuadrat dapat disimpulkan bahwa masing-masing data pre-test pada kelas eksperimen dan kelas kontrol berdistribusi normal.

Uji Homogenitas. Uji homogenitas varians bertujuan untuk melihat apakah hasil pre-test kelas eksperimen dan kelas kontrol mempunyai varians yang homogen atau tidak. Dari hasil perhitungan, rekapitulasi hasil uji homogenitas data pre-test pada kelas eksperimen dan kelas kontrol dapat dilihat pada tabel 2

Tabel 2

Rekapitulasi Hasil Uji

Homogenitas

Data Pre-Test

\begin{tabular}{ccccl}
\hline Data & hitung & KD & tabel & Kesimpulan \\
\hline Pre-Test & 1,39 & $(30: 34)$ & 1,80 & Homogen \\
\hline
\end{tabular}

Dari data di atas dapat diihat bahwa Fhitung kurang dari Ftabel. Sehingga dapat disimpulkan bahwa varians kelas eksperimen dan kelas kontrol adalah homogen.

Uji Kesamaan Dua Rata-rata. Uji kesamaan dua rata-rata bertujuan untuk mengetahui ada tidaknya perbedaan kemampuan pemecahan masalah matematika awal siswa pada kelas eksperimen dan kelas kontrol. Berdasarkan hasil analisis uji normalitas dan uji homogenitas yang telah dilakukan, maka uji kesamaan dua rata- rata yang digunakan adalah uji-t.

Pasangan hipotesis yang digunakan pada pre-test adalah:

Ho: Tidak terdapat perbedaan rata-rata skor pre-test kemampuan pemecahan masalah matematika 
siswa kelas eksperimen dan kelas kontrol

Ha: Terdapat perbedaan rata-rata skor pre-test kemampuan pemecahan masalah matematika siswa kelas eksperimen dan kelas kontrol

Kriteria pengujiannya adalah terima Ho jika thitung ttabel. Untuk harga $t$ yang lainnya Ho ditolak dengan taraf signifikan $=0,05$. Berdasarkan hasil perhitungan, rekapitulasi hasil uji-t data pre-test dapat dilihat pada tabel 3 .

Tabel 3

Rekapitulasi Hasil Uji Kesamaan Dua Rata-rata

\begin{tabular}{ccccc}
\hline Data & & dk & & Kesimpulan \\
& & & & \\
\hline Pre-Test & $-1,45$ & 72 & 2,000 & Ho diterima
\end{tabular}

Berdasarkan tabel 3 di atas dapat dilihat bahwa $<$. Sehingga dapat disimpulkan bahwa tidak terdapat perbedaan rata-rata skor pre-test kemampuan pemecahan masalah matematika siswa kelas eksperimen dan kelas kontrol.

Analisis Inferensial Data PostTest Uji Normalitas. Uji normalitas dilakukan untuk mengetahui apakah data yang diperoleh berdistribusi normal atau tidak. Rumus yang digunakan untuk menghitung uji normalitas adalah chi-kuadrat dengan taraf signifikasi $=0,05$, jika $<$, maka dapat dinyatakan bahwa data berdistribusi normal dan sebaliknya. Rekapitulasi hasil uji normalitas data post-test pada kelas eksperimen dan kelas control dapat dilihat pada tabel 4.

Tabel 4

Rekapitulasi Hasil Uji Homogenitas Data Post-Test

\begin{tabular}{llllll}
\hline No & Kelas & & dk & $\begin{array}{c}\text { Kesimpul } \\
\text { an }\end{array}$ \\
\hline 1 & $\begin{array}{l}\text { Eksperi } \\
\text { men }\end{array}$ & 5,3800 & 5 & 11,070 & Normal \\
\hline 2 & Kontrol & 4,6050 & 6 & 12,592 & Normal \\
\hline
\end{tabular}

Dari tabel 4 di atas dapat dilihat bahwa data post-test untuk kelas eksperimen dan kelas kontrol kurang dari. Dari data di atas dapat diihat bahwa Fhitungkurang dari Ftabel. Sehingga dapat disimpulkan bahwa varians kelas eksperimen dan kelas kontrol adalah homogen.

Uji Perbedaan Dua Rata-rata Ujiperbedaan dua rata-rata $(<)$ bertujuan untuk mengetahui ada tidaknya ketentuan uji normalitas dengan menggunakan chi kuadrat dapat disimpulkan bahwa masingmasing data post-test pada kelas eksperimen dan kelas kontrol berdistribusi normal.

Uji Homogenitas. Uji homogenitas varians bertujuan untuk melihat apakah hasil post-test kelas eksperimen dan kelas kontrol mempunyai varians yang homogen atau tidak. Dari hasil perhitungan, rekapitulasi hasil uji homogenitas data post-test pada kelas eksperimen dan kelas kontrol dapat dilihat pada tabel 5. perbedaan pengaruh model pembelajaran berbasis masalah terhadap kemampuan pemecahan 
masalah matematika siswa pada kelas eksperimen dan model pembelajaran konvensional terhadap kemampuan pemecahan masalah matematika siswa pada kelas kontrol.

Dengan uji perbedaan dua ratarata ini, dapat dibuktikan kebenaran hipotesis yang telah dirumuskan dan memperoleh kesimpulan atas penelitian yang telah dilakukan. Berdasarkan hasil analisis uji normalitas dan uji homogenitas yang telah dilakukan, maka uji perbedaan dua rata-rata yang digunakan adalah uji-t. Pasangan hipotesis yang digunakan pada post-test adalah:

Ho: Kemampuan pemecahan masalah matematika kelas eksperimen kurang dari atau sama dengan kelas kontrol

Ha: Kemampuan pemecahan masalah matematika kelas eksperimen lebih dari kelas kontrol

Kriteria pengujiannya adalah terima Ho jika thitung ttabel. Untuk harga $\mathrm{t}$ yang lainnya Ho ditolak dengan taraf signifikan = 0,05.Berdasarkan hasil perhitungan, rekapitulasi hasil uji perbedaan dua rata- rata dapat dilihat pada tabel 6.

Tabel 6

Rekapitulasi Hasil Perbedaan Dua Rata-rata

\begin{tabular}{lllll}
\hline Data & & $\mathrm{dk}$ & & Kesimpulan \\
\hline Post-Test & 6,80 & 72 & 1,671 & Ho ditolak \\
\hline
\end{tabular}

Berdasarkan tabel 6 di atas dapat dilihat bahwa > sehingga Ho ditolak dan $\mathrm{Ha}$ diterima. Dengan diterimanya $\mathrm{Ha}$, berarti kemampuan pemecahan masalah matematika kelas eksperimen lebih dari kelas kontrol. Keputusan diterimanya $\mathrm{Ha}$ tersebut menjadi landasan membuktikan kebenaran hipotesis yang diajukan dalam penelitian ini. Dengan demikian, dapat dinyatakan bahwa ada pengaruh model pembelajaran berbasis masalah terhadap kemampuan pemecahan masalah matematika siswa kelas XI IPA MA Negeri 1 Lubuklinggau.

\section{PEMBAHASAN}

Hasil penelitian ini menunjukkan bahwa ada pengaruh model pembelajaran berbasis masalah terhadap kemampuan pemecahan masalah matematika siswa kelas XI IPA MA Negeri 1 Lubuklinggau. Pengaruh model pembelajaran berbasis masalah terhadap kemampuan pemecahan masalah matematika yang peneliti tegaskan diperkuat dengan landasan teoritik dan praktik. Secara teoritik, Sanjaya (2014) mengungkapkan bahwa pembelajaran berbasis masalah dapa membantu siswa mentransfer pengetahuan untuk memahami masalah.

Selanjutnya, langkah-langkah pembelajaran berbasis masalah yang dikemukakan Hosnan (2014) yang menjadi rujukan peneliti relevan dengan indicator kemampuan pemecahan masalah. Orientasi siswa pada masalah dapat membantu siswa memahami masalah, mengorganisasikan siswa untuk 
belajar dan membimbing penyelidikan membantu siswa mampu merencanakan dan melakukan penyelesaian masalah, mengembangkan dan menyajikan hasil karya membantu siswa menyusun laporan penyelesaian, dan mengevaluasi proses penyelesaian membantu siswa teliti memeriksa kebenaran penyelesaian.

Sedangkan secara praktik, hasil uji perbedaan dua rata-rata data post-test antarakelas eksperimen dankelas kontro lmembuktikan adanya pengaruh model pembelajaran berbasis masalah terhadap kemampuan pemecahan masalah matematika siswa kelas XI IPA MA Negeri 1 Lubuklinggau.

Pertemuan pertama di kelas eksperimen dengan menggunakan model pembelajaran berbasis masalah, kondisi kelas menjadi gaduh karena banyak siswa tidak mau dikelompokkan sesuai dengan kelompok yang dibentuk dan protes siswa terhadap pemberian masalah tanpa penjelasan materi dari guru terlebih dahulu. Kondisi ini menjadi kondusif setelah diterangkan alasan pengelompokkan yang dibagi secara merata dengan satu orang siswa berkemampuan pemecahan masalah tinggi untuk masing-masing kelompok.

Lebih lanjut, pada proses pembelajarannya masing-masing kelompok masih mengalami kesulitan memahami masalah. Mengatasi ini, berdasarkan langkah pembelajaran yang telah direncanakan, maka dilakukan orientasi masalah secara berulang-ulang secara klasikal dan membantu siswa mengidentifikasi informasi yang diketahui dan ditanyakan pada masalah tersebut.

Pada pertemuan kedua, disajikan masalah matematika terkait permutasi. masalah yang pada pertemuan kedua tetap sama banyak dengan pertemuan pertama yaitu dua masalah. Orientasi masalah pada pertemuan kedua berulang-ulang disampaikan karena sebagian besar siswa masih bingung dengan masalah yang diberikan. Terlebih lagi, beberapa siswa dilibatkan untuk memperagakan kondisi sejenis dengan permasalahan permutasi yang peneliti saijkan agar dapat membantu siswa memahami masalah.

Peningkatan yang terjadi di pertemuan ini, sebagian siswa terlibat aktif mengajukan solusi-solusi pemecahan masalah yang mungkin bisa digunakan. Selebihnya siswa mulai percaya diri mempresentasikan hasil diskusi kelompok meski tidak dapat menyelesaikan masalah dengan sempurna.

Pada pertemuan ketiga, guru menyajikan dan mengorientasikan dua masalah matematika yang berkenaan dengan kombinasi. Hingga pada pertemuan ketiga, secara klasikal siswa di masing-masing kelompok mengalami peningkatan menjadi lebih aktif dan mampu memahami masalah serta merencanakan penyelesaian meskipun masih ada yang salah 
melakukan perhitungan dan lupa memberi penegasan pemeriksaan hasil penyelesaian masalah.

Selama pelaksanaan penelitian, hambatan yang dihadapi adalah rasa ingin tahu siswa masih rendah dan hubungan sosial sesama siswa yang kurang komunikatif. Rendahnya rasa ingin tahu siswa dikarenakan kurangnya kemampuan siswa memahami masalah. Mengatasi masalah ini, siswa diberikan beberapa pertanyaan pengarah dalam mengorientasikan bahkan memperagakan masalah secara berulang-ulang untuk membantu mereka memahami masalah. Selanjutnya, hubungan sosial sesama siswa kurang komunikatif karena kelas XI IPA 3 merupakan perpaduan dari beberapa siswa kelas $\mathrm{X}$ yang cenderung membentuk kelompok pertemanan.

Mengatasi hal ini, dilakukan pendekatan intensif dengan beberapa siswa yang tergolong kurang berkomunikasi agar terbiasa dan membaur dalam bekerja sama dengan kelompok masing-masing.

Keterbatasan yang ditemui selama penelitian dengan menggunakan model pembelajaran berbasis masalah, yaitu 1) keterbatasan waktu dan kesempatan untuk melakukan penelitian, sehingga penggunaan model pembelajaran berbasis masalah hanya dapat peneliti maksimalkan selama kurang lebih tiga kali pertemuan, 2) kesulitan merencanakan dan mensimulasi masalah kontekstual yang akan diberikan, 3) keterbatasan referensi dengan penelitian serupa sebagai pedoman dalam pelaksanaan dan penyusunan hasil penelitian.

\section{SIMPULAN}

Berdasarkan hasil penelitian dan pembahasan, dapat disimpulkan bahwa ada pengaruh model pembelajaran berbasis masalah terhadap kemampuan pemecahan masalah matematika siswa kelas XI IPA MA Negeri 1 Lubuklinggau. Pengujian hipotesis menggunakan uji-t dengan taraf signifikasi $=0,05$ dan derajat kebebasan $(\mathrm{dk})=72$, diperoleh $>(6,80>1,671)$. Dengan demikian hipotesis yang diajukan dalam penelitian ini diterima.

\section{DAFTAR PUSTAKA}

Abdurahman, M. (2012). Anak Berkesulitan Belajar. Jakarta: Rineka Cipta.

Hosnan. (2014). Pendekatan Saintifik dan Kontekstual dalam Pembelajaran Abad 21. Bogor: Ghalia Indonesia.

Sani. R. (2014). Pembelajaran Saintifik untuk Implementasi Kurikulum 2013. Jakarta: BumiAksara.

Sanjaya, W. (2014). Strategi Pembelajaran Berorientasi Standar Proses Pendidikan. Jakarta: Kencana Prenada Media Group.

Suherman. (2001). Commond Text Book Strategi Pembelajaraan Matematika Kontemporer. Bandung: JICA Universitas Pendidikan Indonesia (UPI). 